\title{
Somatic cell nuclear transfer in the sheep induces placental defects that likely precede fetal demise
}

\author{
C J Fletcher, C T Roberts, K M Hartwich ${ }^{1}$, S K Walker ${ }^{2}$ and I C McMillen ${ }^{1}$
}

Research Centre for Reproductive Health, Discipline of Obstetrics and Gynaecology, School of Paediatrics and Reproductive Health, University of Adelaide, Adelaide SA 5005, Australia, ${ }^{1}$ Research Centre for the Early Origins of Adult Health, Discipline of Physiology, School of Molecular and Biomedical Science, University of Adelaide, Adelaide SA 5005, Australia and ${ }^{2}$ South Australia Research and Development Institute, Turretfield Research Centre, Rosedale SA 5350, Australia

Correspondence should be addressed to IC McMillen; Email: caroline.mcmillen@unisa.edu.au

I C McMillen is now at Research Centre for the Early Origins of Adult Health, Sansom Institute, School of Pharmacy and Medical Science, University of South Australia, City East Campus, Playford Building, Frome Road, Adelaide SA 5000, Australia

\begin{abstract}
The efficiency of cloning by somatic cell nuclear transfer (SCNT) is poor in livestock with $\sim 5 \%$ of transferred cloned embryos developing to term. SCNT is associated with gross placental structural abnormalities. We aimed to identify defects in placental histology and gene expression in failing ovine cloned pregnancies to better understand why so many clones generated by SCNT die in utero. Placentomes from SCNT pregnancies $(n=9)$ and age matched, naturally mated controls $(n=20)$ were collected at two gestational age ranges (105-134 days and 135-154 days; term $=147$ days). There was no effect of cloning on total placental weight. However, cloning reduced the number of placentomes at both gestational ages (105-134 days: control $55.0 \pm 4.2$, clone $44.7 \pm 8.0$ and 135-154 days: control $72.2 \pm 5.1$, clone $36.6 \pm 5.1 ; P<0.001)$ and increased the mean individual placentome weight (105-134 days: control 10.6 $\pm 1.3 \mathrm{~g}$, clone 18.6 $\pm 2.8 \mathrm{~g}$ and 135-154 days: control $6.6 \pm 0.6 \mathrm{~g}$, clone $7.0 \pm 2.0 \mathrm{~g} ; P<0.02$ ). Placentomes from cloned pregnancies had a significant volume of shed trophoblast and fetal villous hemorrhage, absent in controls, at both gestational age ranges $(\boldsymbol{P}<\mathbf{0 . 0 0 1})$ that was shown to be apoptotic by activated caspase-3 immunoreactivity. Consequently, the volume of intact trophoblast was reduced and the arithmetic mean barrier thickness of trophoblast through which exchange occurs was altered $(P<0.001)$ at both gestational age ranges in clones. In addition, cloning reduced placental expression of key genes in placental differentiation and function. Thus, cloning by SCNT results in both gross and microscopic placental abnormalities. We speculate that trophoblast apoptosis, shedding, and hemorrhage may be causal in fetal death in ovine clones. Reproduction (2007) 133 243-255
\end{abstract}

\section{Introduction}

Embryos and fetuses have successfully been generated using somatic cell nuclear transfer (SCNT) in a range of species (Wells et al. 1997, 1999, Wilmut et al. 1997, Wakayama et al. 1998, Hill et al. 2000). In livestock, however, cloning by SCNT is inefficient with $<5 \%$ of blastocysts developing through to term (Wilmut et al. 1997, Cibelli et al. 1998, Kato et al. 1998, De Sousa et al. 2001). In studies in cattle and sheep, approximately half of implanted nuclear transfer (NT) embryos fail to complete the early stages of development, while the majority of those that develop further have gross abnormalities such as fetal overgrowth, respiratory failure, abnormal kidney development, and liver steatosis (Chavatte-Palmer et al. 2004). In addition, placental abnormalities have been observed in pregnancies generated by NT and it has been proposed that these may contribute to the increase in fetal morbidity and mortality (Wells et al. 1997, Hill et al. 2000, 2001b, De Sousa et al. 2001, Hashizume et al. 2002, Lee et al. 2004). The types of placental abnormalities present in ruminant cloned pregnancies in early gestation include reduced numbers of placentomes (Hill et al. 2000, De Sousa et al. 2001, Chavatte-Palmer et al. 2002, Hashizume et al. 2002, Lee et al. 2004) and increased size of placentomes accompanied by edematous and/or hemorrhagic changes (Hill et al. 2001 a, Chavatte-Palmer et al. 2002, Lee et al. 2004). Cloning in mice results in placentomegaly (Tanaka et al. 2001). In addition, aberrant placental expression of the major histocompatibility complex (MHC-I) has been demonstrated in 
bovine clones and speculated that this may contribute to immunological rejection and early embryonic loss (Hill et al. 2002).

Whilst there is evidence that abnormal placental development may contribute to the poor survival rate of the cloned fetus, no studies have investigated the specific impact of reproductive cloning on the development of placental microstructure using quantitative or morphometric techniques in the sheep. Analysis of placental microstructure can provide insight into placental function and nutrient transfer to the fetus. Thus, quantification of each placentome component in terms of its volume density (proportion), volume, and exchange surface (surface density, surface area, and barrier thickness) can provide valuable understanding of the effect cloning has on placental structure and function. As the vast majority of cloned pregnancies are unsuccessful, we aimed to elucidate the placental defects in failing mid to late term cloned pregnancies by comparing placental development in SCNT generated pregnancies and those generated by natural mating. In addition, immunoreactivity for activated caspase- 3 was employed to identify apoptotic cells in cloned placental tissue at post-mortem.

\section{Materials and Methods}

All procedures were approved by the University of Adelaide Animal Ethics Committee as well as the Primary Industry and Resources South Australia (PIRSA) Animal Ethics Committee.

\section{Donor cell collection, treatment, and nuclear transfer}

Oocyte collection and SCNT methods for this study have been previously described (Edwards et al. 2002, Peura et al. 2003). Briefly, donor granulosa cells were obtained from an adult Merino ewe and cultured for 2-3 passages. Cells were serum starved and then cryo-preserved before being used. Oocyte enucleation and donor cell injection were performed concurrently in batches of 10-20 oocytes. Success of enucleation was confirmed by viewing the contents of the enucleation pipette under UV light. A donor cell was then injected into the perivitelline space and fused with an $\mathrm{AC}$ alignment pulse of $400 \mathrm{kHz}$ and $10 \mathrm{~V}$ followed by two AC/DC fusion pulses of $1.25 \mathrm{kV} / \mathrm{cm}$. Successfully fused couplets were incubated and cultured. Blastocysts that developed were then transferred to synchronized recipient ewes.

\section{Embryo transfer and pregnancy monitoring}

A 12-day intravaginal progestagen pessary (45 mg flugestone acetate; Laboratorie Pharmaceutique Porges, Paris, France) and i.m. injection of equine chorionic gonadotropin (eCG, $400 \mathrm{IU}$; Bioniche Animal Health,
Armidale, Australia) were used to synchronize recipient ewes. Embryo transfers were performed approximately 6 days after the expected time of ovulation in the recipient ewe. One to three embryos were transferred laparoscopically into the uterine horn ipsilateral to the corpus luteum. Pregnancy was confirmed by ultrasonography between 40 and 60 days of pregnancy.

At 105-115 days gestation, surgery was performed under general anesthesia initially induced with sodium thiopentone (1.25 g i.v. Pentothal; Rhone Merieux, Pinkenba, Qld Australia) and maintained with halothane (2.5-4\% Fluothane; ICl, Melbourne, Vic, Australia) in oxygen. Vascular catheters were inserted into a fetal carotid artery and jugular vein, the maternal jugular vein and into the amniotic cavity as previously described (Edwards et al. 1999). Vascular catheters were inserted into one fetus in twin pregnancies. If, at the time of surgery, the fetus to be catheterized had died then the fetus and its live twin, if present, were taken immediately to post-mortem for tissue collection. All the catheters were filled with heparinized saline and an external excision in the ewe's flank was made to exteriorize the fetal catheters. All ewes and fetal sheep received a $2 \mathrm{ml}$ i.m. injection of antibiotics (procaine penicillin $250 \mathrm{mg} / \mathrm{ml}$; dihydrostreptomycin $250 \mathrm{mg} / \mathrm{ml}$; procaine hydrochloride $20 \mathrm{mg} / \mathrm{ml}$, Penstrep Illium, Troy Laboratories, Smithfield, NSW, Australia) at the time of surgery. The ewes were housed in individual pens in animal holding rooms with a $12 \mathrm{~h}$ light: $12 \mathrm{~h}$ darkness cycle.

\section{Blood sample collection}

Fetal carotid arterial blood samples $(0.5 \mathrm{ml})$ were collected for 4 consecutive days and then 3-7 times per week thereafter to assess fetal health (ABL 520 blood gas analyzer; Radiometer, Copenhagen, Denmark). Fetal carotid artery and maternal venous blood samples (2-5 $\mathrm{ml}$ and $3-5 \mathrm{ml}$ respectively) were collected at the time of, and just prior to, post-mortem. All blood collected was centrifuged at $1500 \mathrm{~g}$ for $10 \mathrm{~min}$ and the plasma aliquoted and stored at $-20^{\circ} \mathrm{C}$ prior to glucose assay.

\section{Tissue collection}

Table 1 displays the total number of fetuses in each group from which placental and fetal weight data, fetal plasma glucose concentrations and placental morphometric data were obtained. The placentae were grouped into either an early age group (105-134 days gestation) or a later age group (135-154 days gestation) as significant placental maturation occurs after 135 days of gestation. This is known to be due to the activation of the fetal hypothalamic-pituitary-adrenal (HPA) axis that occurs between 134 and 136 days of gestation and elevated circulating fetal cortisol (Challis \& Brooks 1989). In the early age group, two of the six cloned fetuses had died 
Table 1 Number of animals in each treatment group for morphometric or glucose analysis.

\begin{tabular}{|c|c|c|c|c|}
\hline & \multicolumn{2}{|c|}{ 105-134 days GA } & \multicolumn{2}{|c|}{ 135-154 days GA } \\
\hline & Control & Clone & Control & Clone \\
\hline Placental and fetal weight & 22 & 6 & 18 & 5 \\
\hline Plasma glucose analysis & 11 & 6 & 9 & 5 \\
\hline $\begin{array}{l}\text { Morphometric analysis of } \\
\text { placenta }\end{array}$ & 14 & 5 & 6 & 4 \\
\hline Placental gene expression & 5 & 1 & 7 & 3 \\
\hline
\end{tabular}

and four were declining in health as indicated by consecutive arterial blood gas samples (decreasing $\mathrm{pH}$ and/or arterial $\mathrm{PO}_{2}$ ). Placental tissue (fetal death $<24 \mathrm{~h}$ before post-mortem) from five fetuses was collected in this group (Table 2). In the later age group, one of the five cloned fetuses had died and four were in declining health at the time of tissue collection. Placental tissue was collected from four fetuses in this group (Table 2). Placentae were also collected from control ewes that were matched for fetal number and age (104-134 days, $n=14 ; 135-145$ days, $n=6$ ). At the time of tissue collection, the ewes were killed with an overdose of sodium pentobarbitone (Virbac, Peakhurst, NSW, Australia) and the fetuses were removed by hysterectomy, weighed and killed by decapitation. Placentomes were excised from the uterus and weighed. Three placentomes (either A, B, C, or D) (Alexander 1964a, 1964b, Vatnick et al. 1991) were randomly selected and fixed in $4 \%$ paraformaldehyde in $70 \mathrm{mM}$ phosphate buffer $(\mathrm{pH} 7.4)$ prior to embedding in paraffin.

\section{Placental morphometry}

Placental sections $(5-7 \mu \mathrm{m})$ were cut and stained using the Masson's trichrome technique (Weibel 1979, Drury \& Wallington 1980, Roberts et al. 2001). Sections were examined with a $4 \times$ objective lens and a $2.5 \times$ ocular lens, using an Olympus $\mathrm{BH} 2$ microscope with a Video Image Analysis system using Video Pro software (Leading Edge, NSW, Australia). The volume density or proportion of placentome composed of each placental component (maternal epithelium, maternal capillaries, maternal connective tissue, trophoblasts, fetal capillaries, and fetal connective tissue) was quantified using point counting with an isotropic L-36 Merz transparent grid placed on the monitor screen. Ten fields (360 points)

Table 2 Fetal outcome at post-mortem for placental morphometric analysis.

\begin{tabular}{lcccccc}
\hline & \multicolumn{2}{c}{$\mathbf{1 0 5 - 1 3 4}$ days GA } & & \multicolumn{1}{c}{$\mathbf{1 3 5 - 1 5 4}$ days GA } \\
\cline { 2 - 3 } \cline { 5 - 6 } & Control & Clone & & Control & Clone \\
\hline Alive & 14 & 3 & & 6 & 3 \\
Tissue collected within & 0 & 2 & & 0 & 1 \\
$2-24$ h of fetal death & & & & & \\
\hline
\end{tabular}

were counted in one section per placentome per ewe. The first field location was chosen at random within the zona intima and the following fields were systematically selected $1 \mathrm{~mm}$ apart using the stage micrometer. Volume density (proportion) of each placentome component was calculated using:

Volume density $\left(V_{\mathrm{d}}\right)=\frac{P_{\mathrm{a}}}{P_{\mathrm{T}}}$

where $P_{\mathrm{a}}$ is the total number of points falling on that component and $P_{\mathrm{T}}$ is the total number of points applied to the section (Weibel 1979, Roberts et al. 2001). The estimated volume of placental components was obtained by multiplying the $V_{\mathrm{d}}$ by the placentome weight (g).

Measures of the trophoblast exchange surface include surface density, surface area, and barrier thickness and are indicative of transport capacity between maternal and fetal circulations. The surface density (surface area per gram of placenta) of trophoblast is a measure of how convoluted and interdigitated the maternal and fetal tissues are and a representative quantification is obtained by line intercept counting using the same grid and the same fields for determining $V_{d}$ of components. An estimation of surface density was calculated as follows:

Surface density $\left(S_{\mathrm{v}}\right)=2\left(\frac{I_{\mathrm{a}}}{L_{\mathrm{T}}}\right)$

where $I_{a}$ is the number of intercepts with the grid line and $L_{T}$ is the total length of the lines applied (Weibel 1979, Roberts et al. 2001). A representation of the total surface area (SA) of the placentome was obtained by multiplying $S_{\mathrm{v}}$ by the weight of the placentome. The greater the surface area, the greater the potential for nutrient and gaseous exchange between maternal and fetal circulations. The arithmetic mean barrier thickness of trophoblast is a measure of the distance through which nutrients, gases, and wastes are exchanged within the placentome. The thinner the barrier, the greater the opportunity for exchange. The arithmetic mean barrier of trophoblast to diffusion was calculated as follows:

Barrier thickness $\left(B_{\mathrm{T}}\right)=\frac{V_{\mathrm{d}}}{S_{\mathrm{v}}}$

To determine the reproducibility of the method, observations on one section were performed five times. The coefficient of variation of these measurements was $<8.5 \%$. A representation of the total placental volumes and surface area were calculated using volume density and surface density multiplied by total placental weight. Such measurement employs the assumption that all placentomes have similar morphometry to that of the most abundant type. 


\section{Immunohistochemistry}

Immunohistochemistry was performed on $6 \mu \mathrm{m}$ paraffinembedded sections. These were first deparaffinized in safsolvent (Ajax Chemicals, Auburn, NSW, Australia) and subjected to antigen retrieval by incubating at $37{ }^{\circ} \mathrm{C}$ for $15 \mathrm{~min}$ in $0.03 \%$ pronase (Sigma). The sections were then blocked for endogenous peroxidase activity with $3 \%$ hydrogen peroxide at room temperature for $40 \mathrm{~min}$ and blocked with $10 \%$ goat serum and $1 \%$ BSA in $1 \times$ PBS at room temperature for $10 \mathrm{~min}$ to prevent nonspecific binding. The primary antibody, affinity purified rabbit anti-human/mouse activated caspase-3 antibody (1:1000: R\&D Systems, NSW, Australia) was diluted in $10 \%$ goat serum and $1 \%$ BSA in $1 \times$ PBS and incubated on sections at room temperature in a humidity chamber overnight. The sections were then washed three times in $1 \times$ PBS and incubated at room temperature for $1 \mathrm{~h}$ with a secondary biotinylated goat anti-rabbit IgG antibody (1:200: Dako, Denmark) and washed three times again in $1 \times$ PBS. The streptavidin-peroxidase label $(1: 250$ : Zymed, San Francisco, USA) was applied for $1 \mathrm{~h}$ at room temperature and sections were washed again three times in $1 \times$ PBS. A brown precipitate was developed at the site of activated anti-caspase-3 binding by incubating with diaminobenzidene (DAB) for $5 \mathrm{~min}$ at room temperature. Negative controls used irrelevant rabbit $\operatorname{lgG}$ in place of the primary antibody.

\section{Glucose assay}

Glucose concentrations in the plasma were enzymatically measured using hexokinase and glucose6-phosphate dehydrogenase. This method measures the formation of NADH photometrically at $340 \mathrm{~nm}$ (COBAS MIRA automated analysis system; Roche Diagnostica). The assay was able to detect glucose at concentrations as low as $0.5 \mathrm{mmol} / \mathrm{l}$ with a coefficient of variation of $<5 \%$.

\section{Placental gene expression}

To determine the impact of cloning on placental gene expression, real time RT-PCR was performed to quantify insulin-like growth factor (IGF)-I, the type 1 IGF receptor (IGF1R), IGF-II, the type 2 IGF receptor (IGF2R) and glucose transporters (GLUT) 1, 3, and 8 mRNAs relative to housekeeper cyclophilin mRNA. The analyzed tissue was only that which had been collected from placentae associated with living fetuses at the time of post-mortem so we can be sure that the mRNA was of good quality in clones. Total RNA from a midsagittal slice of either a B or C type placentome in both the clone and the control groups, irrespective of age, was extracted using Trizol reagent (Invitrogen Life Technologies) according to the manufacturer's instructions. Total RNA (2 $\mu \mathrm{g})$ was reversetranscribed using superscript III reverse transcriptase (Invitrogen Life Technologies) and random oligohexamers $(100 \mu \mathrm{M})$ for priming according to the manufacturer's instructions. Oligonucleotide primers specific to sheep mRNA IGF-I, IGF1R, IGF-II, IGF2R, GLUT-1, GLUT-3, and GLUT-8 were designed using Primer Express software (Applied Biosystems, Foster City, CA). The primer sequences, amplicon size and GeneBank accession numbers are shown in Table 3. Primer extension was performed using the ABI PRISM 7000-sequence detection system and SYBR Green I chemistry to detect synthesized products. Thermocycling parameters were set according to the manufacturer's instructions. The mRNA expression levels for the above genes were quantified using the Qgene method (Simon 2003).

\section{Statistical analysis}

All data are represented as the mean \pm S.E.M. All the values for placentome weight, number, morphometry, and gene expression were analyzed using SPSS software (Statistical Package for Social Scientists statistical software, SPSS, v. 13 Chicago, USA). Placental and fetal

Table 3 Primer sequences for real time RT-PCR.

\begin{tabular}{|c|c|c|c|}
\hline Gene & Primer sequence & Amplicon size (bp) & Accession number \\
\hline$I G F-I$ & $\begin{array}{l}\text { Forward: } 5^{\prime} \text { ttggtggatgctctccagttc } 3^{\prime} \\
\text { Reverse: } 5^{\prime} \text { gaatcgtggatagtgctgct } 3^{\prime}\end{array}$ & 116 & DQ152962 \\
\hline$I G F 1 R$ & $\begin{array}{l}\text { Forward: } 5^{\prime} \text { aagaaccatgcctgcagaagg } 3^{\prime} \\
\text { Reverse: } 5^{\prime} \text { aatgcccagaacctgagaatcc } 3^{\prime}\end{array}$ & 104 & AY162434 \\
\hline$I G F-I I$ & $\begin{array}{l}\text { Forward: } 5^{\prime} \text { gcttcttgccttcttggcctt } 3^{\prime} \\
\text { Reverse: } 5^{\prime} \text { atccagccgcataaaccga } 3^{\prime}\end{array}$ & 151 & M89789 \\
\hline$I G F 2 R$ & $\begin{array}{l}\text { Forward: } 5^{\prime} \text { gatgaaggaggctgcaaggat } 3^{\prime} \\
\text { Reverse: } 5^{\prime} \text { aagctggactacaggcatcagg } 3^{\prime}\end{array}$ & 103 & AF327649 \\
\hline GLUT-1 & $\begin{array}{l}\text { Forward: } 5^{\prime} \text { taaccgcaacgaggagaacc } 3^{\prime} \\
\text { Reverse: } 5^{\prime} \text { ccacgcagcttcttcagca } 3^{\prime}\end{array}$ & 51 & U89029 \\
\hline GLUT-3 & $\begin{array}{l}\text { Forward: } 5^{\prime} \text { tgattttgggccgactgatta } 3^{\prime} \\
\text { Reverse: } 5^{\prime} \text { cacgaatcctgtgcagagtcc } 3^{\prime}\end{array}$ & 56 & L39214 \\
\hline GLUT-8 & $\begin{array}{l}\text { Forward: } 5^{\prime} \text { atgccgtcatgttctatgcg } 3^{\prime} \\
\text { Reverse: } 5^{\prime} \text { ccttgaacttggcctcctca } 3^{\prime}\end{array}$ & 51 & AF495799 \\
\hline Cyclophilin & $\begin{array}{l}\text { Forward: } 5^{\prime} \text { cctgctttcacagaataattccag } 3^{\prime} \\
\text { Reverse: } 5^{\prime} \text { catttgccatggacaagatgccag } 3^{\prime}\end{array}$ & 156 & BC105173 \\
\hline
\end{tabular}


parameters, as well as placentome morphometry and plasma glucose concentrations, were analyzed using a two-way ANOVA with treatment and gestational age groups as the main factors. A probability level of $P \leq 0.05$ was considered significant.

\section{Results}

\section{Placental weight and placentome size number and distribution}

There was no significant difference in fetal weight or total placental weight between cloned and control pregnancies either before or after 135-day gestation (Table 4). Fetal weight was lower $(P<0.001)$ in early pregnancy when compared with late pregnancy in both groups. However, placental weight was lower $(P<0.005)$ in late pregnancy when compared with early pregnancy in both groups. There was a significant reduction in the number of placentomes in cloned compared with control pregnancies both before and after 135-day gestation $(P<0.001$; Table 4). There was also a significant interaction between the effects of cloning and gestational age on the mean weight of the placentomes $(P<0.04)$. Whilst mean placentome weight was greater $(P<0.02)$ in cloned compared with control pregnancies before 135 days gestation, there was no difference in the mean placentome weights between clones and controls after 135 days gestation.

In both the early and the later age groups, there was a significant difference in the distribution of placentome types (data not shown). In both age groups, the controls tended to have more A- and B-type placentomes, while the clones tended to have a more even spread over the four types.

\section{Placental histology}

To determine whether cloning leads to microstructural placental abnormalities, placental histology was assessed. The most striking difference in the placentae from cloned, compared with control, pregnancies was the presence of trophoblast that had apparently been shed from the fetal villi (Fig. 1). The 'shed trophoblast' was only present in placentae from cloned animals and not in controls. It was localized between fetal villi and maternal crypts and was associated with, presumably fetal, blood. For the purposes of morphometric analysis, we classified any trophoblast present at the edge and tips of the fetal villi as 'intact trophoblast' and that which was detached from the fetal villi as 'shed trophoblast'. The shed trophoblast was a more dominant feature of the cloned placentae in the early compared with the late gestational age group.

\section{Volume density placentome components}

There were no differences in the proportions (volume density) of maternal epithelium, maternal capillaries, and maternal connective tissue in cloned compared with control placentomes before or after 135 days of gestation (Fig. 2A and C). The volume density of fetal capillaries was significantly increased $(P<0.04)$ in both cloned and control placentae in the later age group compared with the early age group. The presence of shed, and presumably non-functional, trophoblast in clone placentomes resulted in a reduction in the volume density of intact trophoblast in clones compared with controls ( $P<0.001$; Fig. $2 \mathrm{~B}$ and D). When the total amount of trophoblast was calculated (i.e. shed+intact trophoblast), there was no difference in the volume density of 'total' trophoblast in clones when compared with controls.

To establish that differences in volume densities observed in the cloned fetuses were not due to fetal death, a comparison of each component was made between placentomes from clones that were alive and those that were dead. The only volume density affected by fetal state at tissue collection (dead/alive) was that of total trophoblast, which was significantly greater in placentomes from dead fetuses $(0.51 \pm 0.02)$ than live fetuses $(0.40 \pm 0.01 ; P<0.003)$.

\section{Volume of placentome components}

There was a significant interaction between the effects of treatment and gestational age on the volumes of maternal epithelium $(P<0.01)$, capillaries $(P<0.05)$, and connective tissue $(P<0.0001)$. The volumes of maternal epithelium $(P<0.0001)$ and maternal connective tissue $(P<0.0001)$ were each increased in placentomes from clones compared with controls at both

Table 4 Effect of cloning on fetal and placental growth.

\begin{tabular}{|c|c|c|c|c|}
\hline & \multicolumn{2}{|c|}{ 105-134 days GA } & \multicolumn{2}{|c|}{ 135-154 days GA } \\
\hline & Control $(n=22)$ & Clone $(n=6)$ & Control $(n=18)$ & Clone $(n=5)$ \\
\hline Fetal weight (kg) & $2.5 \pm 0.3$ & $2.8 \pm 0.8$ & $4.6 \pm 0.2^{\mathrm{a}}$ & $4.8 \pm 0.7^{\mathrm{a}}$ \\
\hline Total placental weight (g) & $601.5 \pm 46.6$ & $799.2 \pm 172.4$ & $512.4 \pm 55.3^{a}$ & $386.2 \pm 52.7^{\mathrm{a}}$ \\
\hline Total placentome number & $55.0 \pm 4.2$ & $44.7 \pm 8.0^{\mathrm{b}}$ & $72.2 \pm 5.1$ & $36.6 \pm 5.1^{\mathrm{b}}$ \\
\hline Mean placentome weight (g) & $10.6 \pm 1.3$ & $18.6 \pm 2.8^{b}$ & $6.6 \pm 0.6$ & $7.0 \pm 2.0$ \\
\hline
\end{tabular}

${ }^{\mathrm{a} D i f f e r e n c e ~ b e t w e e n ~ t h e ~ e a r l y ~ a n d ~ t h e ~ l a t e r ~ a g e ~ g r o u p . ~}{ }^{\mathrm{b}}$ Difference between treatment group (clone or control). 

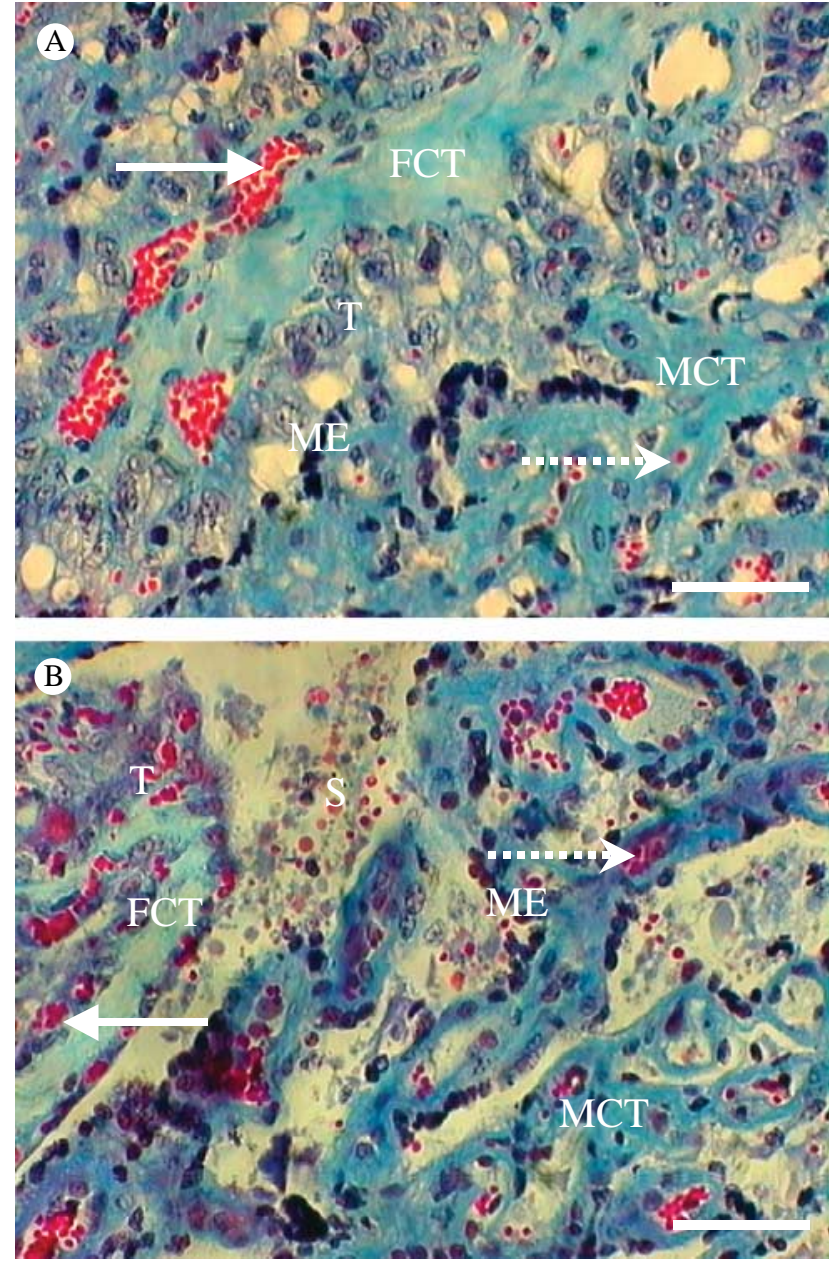

Figure 1 Placentome sections from a control pregnancy (A) and a cloned pregnancy (B) collected after 135 days gestation. ME, maternal epithelium; MCT, maternal connective tissue; T, trophoblast; FCT, fetal connective tissue; $\mathrm{S}$, fetal shed trophoblast. Solid arrow indicates fetal capillaries and broken arrow indicates maternal capillaries. Scale bars $=50 \mu \mathrm{m}$.

gestational age ranges. The volume of the maternal capillaries was greater in the placentomes from clones than in controls in the early age group (Fig. 3A and C). The volume of fetal capillaries was significantly $(P<0.001)$ increased in cloned compared with control pregnancies across both ages (Fig. 3B and D). There was a significant interaction $(P<0.05)$ between the effects of treatment and gestational age on the volume of fetal connective tissue. The volume of fetal connective tissue was significantly greater $(P<0.003)$ in clones compared with controls in the early age group, but not in the later age group (Fig. 3B and D). The volume of intact trophoblast present in the cloned and control placentomes was not different, however, either before or after 135 days of gestation. There was an interaction between the effects of treatment and age on the volume of shed trophoblast. Whilst shed trophoblast was only present in cloned placentae at both ages, the volume of shed trophoblast was significantly higher in clones $(P<0.009)$ in the early age group compared with the later age group (Fig. 3B and D). Similarly, there was an interaction $(P<0.0001)$ between the effects of age and treatment on the volume of total trophoblast. Whilst shed trophoblast was present in cloned but absent in control placentae at both ages, there was a significant decrease with increasing gestational age in the volume of this component of the placenta in the clones.

\section{Placentome trophoblast exchange surface}

The surface density of trophoblast in the placentome was not different between clones and controls and did not change with increasing gestational age (Fig. 4A and B). The surface area of trophoblast for exchange, however, was significantly affected by age and treatment. In the early, but not the later, age group there was fourfold increase $(P<0.0001)$ in the surface area of the placentome in clones compared with controls (Fig. 4C and D). When barrier thickness was calculated based on the total amount (shed+intact) of trophoblast, it was increased $(P<0.05)$ in clones compared with controls across both gestational ages (Fig. 4G and $\mathrm{H}$ ). The barrier thickness (based on intact trophoblast), was however significantly reduced $(P<0.001)$ in clones compared with controls across both gestational ages (Fig. 4E and F). None of these placental parameters were influenced by fetal state at tissue collection.

\section{Total placental volume and surface area}

There was a significant interaction between the effects of age and treatment on the volume of the maternal epithelium $(P<0.03)$ and connective tissue $(P<0.003)$ in the placenta. Whilst the volumes of the maternal epithelium and connective tissue present in the clone placenta were each double $(P<0.01)$ those present in the controls in the early age group, there was no difference between clones and controls in the later age group (Fig. 5A and C). There was no difference in the volume of maternal capillaries in the placenta between clones and controls at either age range.

The volumes of fetal capillaries and fetal connective tissue present in the placenta were also not different in clones compared with controls before or after 135 days of gestation (Fig. 5B and D). The volume of intact trophoblast was significantly lower in clones compared with controls $(P<0.05$; Fig. $5 \mathrm{~B}$ and $\mathrm{D})$. The volume of shed trophoblast was significantly higher in clones $(P<0.04)$ in the early age group compared with the later age group (Fig. 5B and D). Whilst the volume of total trophoblast was significantly higher in clones compared with controls before 135 days, there was no such difference after 135-day gestation (Fig. 5B and D). The calculated total surface area of trophoblast for 

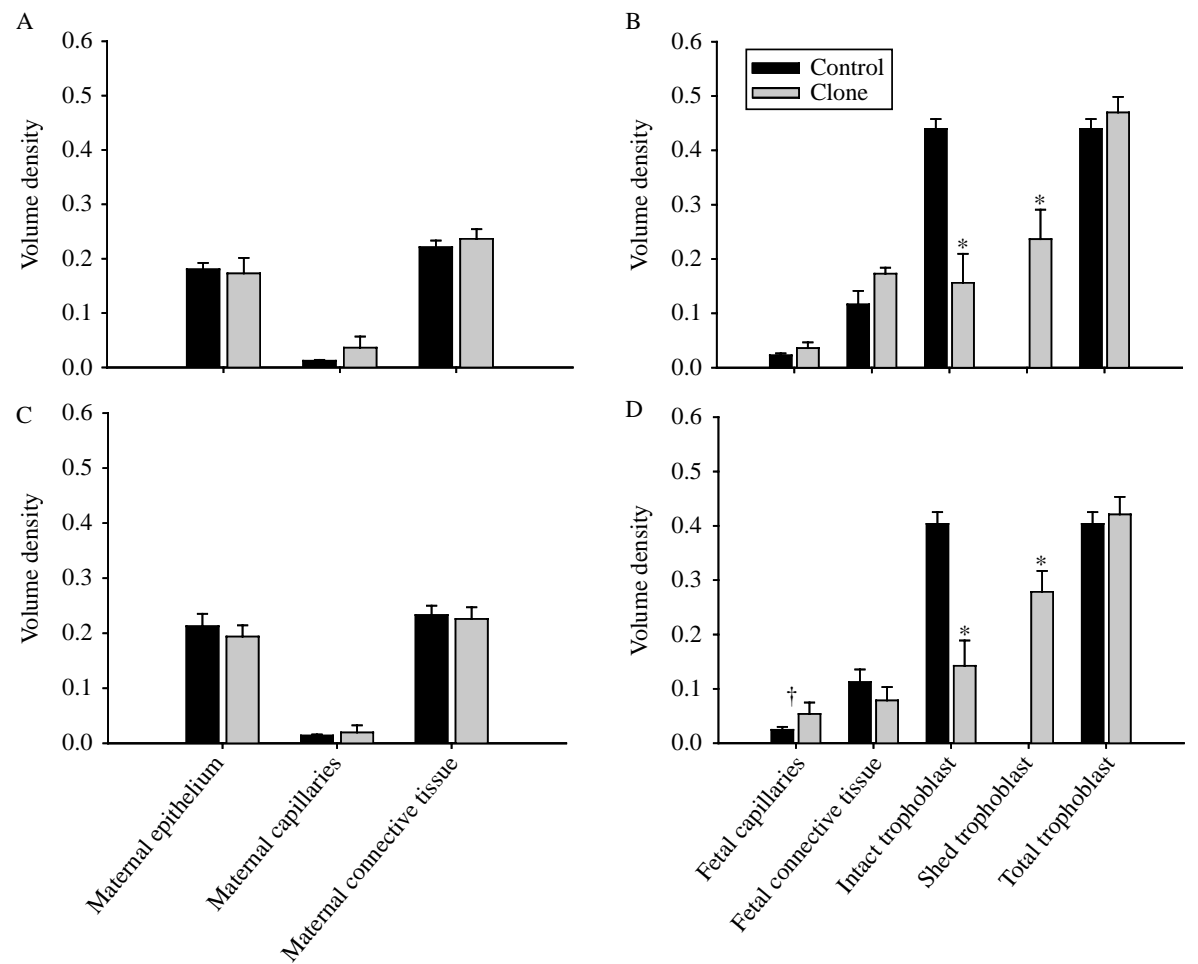
Figure 2 Volume density (mean \pm S.E.M.) of each placental component before 135-day gestation ( $A$ and $B$ ) and after 135-day gestation ( $C$ and $D)$ in placen- tomes collected from control and clone animals. *Denotes different from control $P \leq 0.05$. ${ }^{\dagger}$ Denotes difference between the early and the later age groups $P<0.05$. GA 105-134-day control $n=14$, clone $n=5$ and GA $135-154$ days control $n=6$ and clone $n=4$.

exchange was not altered by gestational age in controls. However, in clones, surface area was reduced in the older age group $(P<0.05)$ in comparison to the early age group (Fig. 6A and $\mathrm{B}$ ).
The volume of fetal capillaries was significantly reduced in dead $(3.166 \pm 5.264)$ compared with alive fetuses $\left(27.64 \pm 4.16 \mathrm{~cm}^{3} ; P<0.02\right)$. The total placental volume of fetal connective tissue was reduced in dead

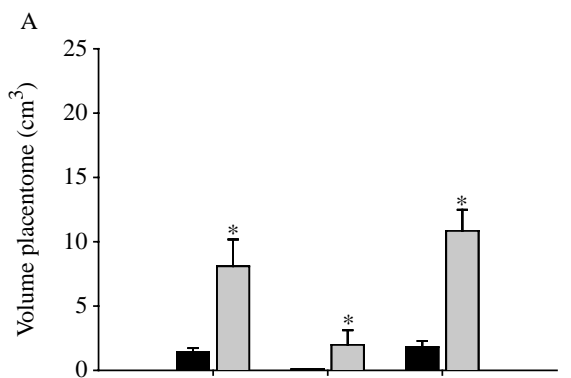

B
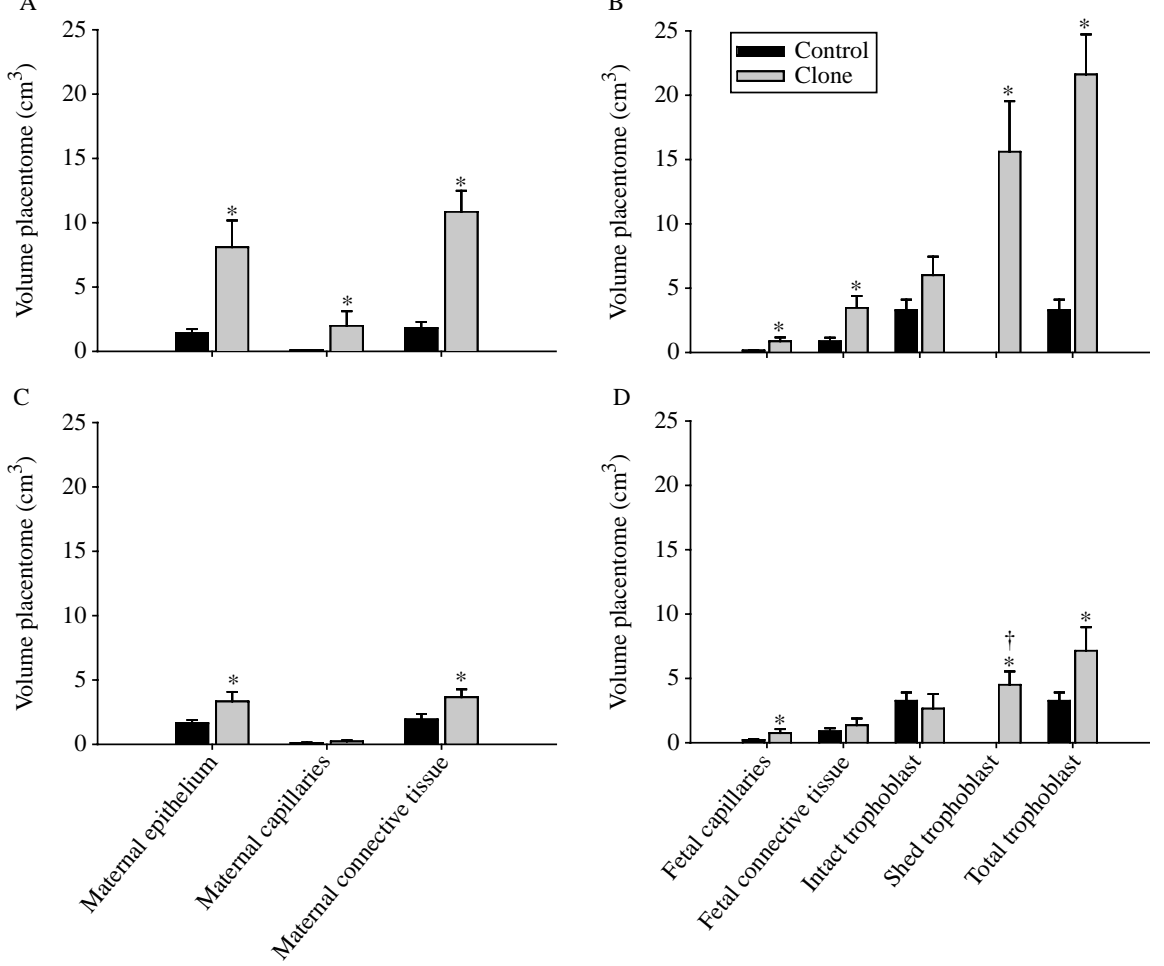

$\mathrm{D}$

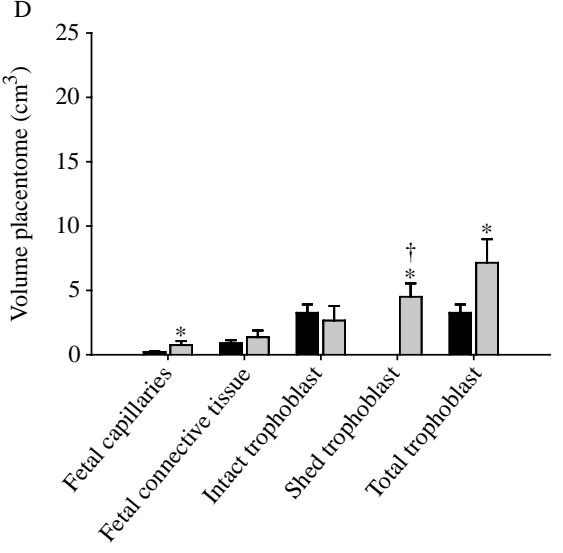

Figure 3 Volume (mean \pm s.E.M.) of each placental component in the placentome before 135 days gestation ( $\mathrm{A}$ and B) and after 135 days gestation (C and D) in placentomes collected from control and cloned animals. *Denotes different from control $P \leq 0.05$.

${ }^{\dagger}$ Denotes difference between the early and the later age groups $P<0.05$. GA 105-134 days control $n=14$, clone $n=5$ and GA $135-154$ days control $n=6$ and clone $n=4$. 

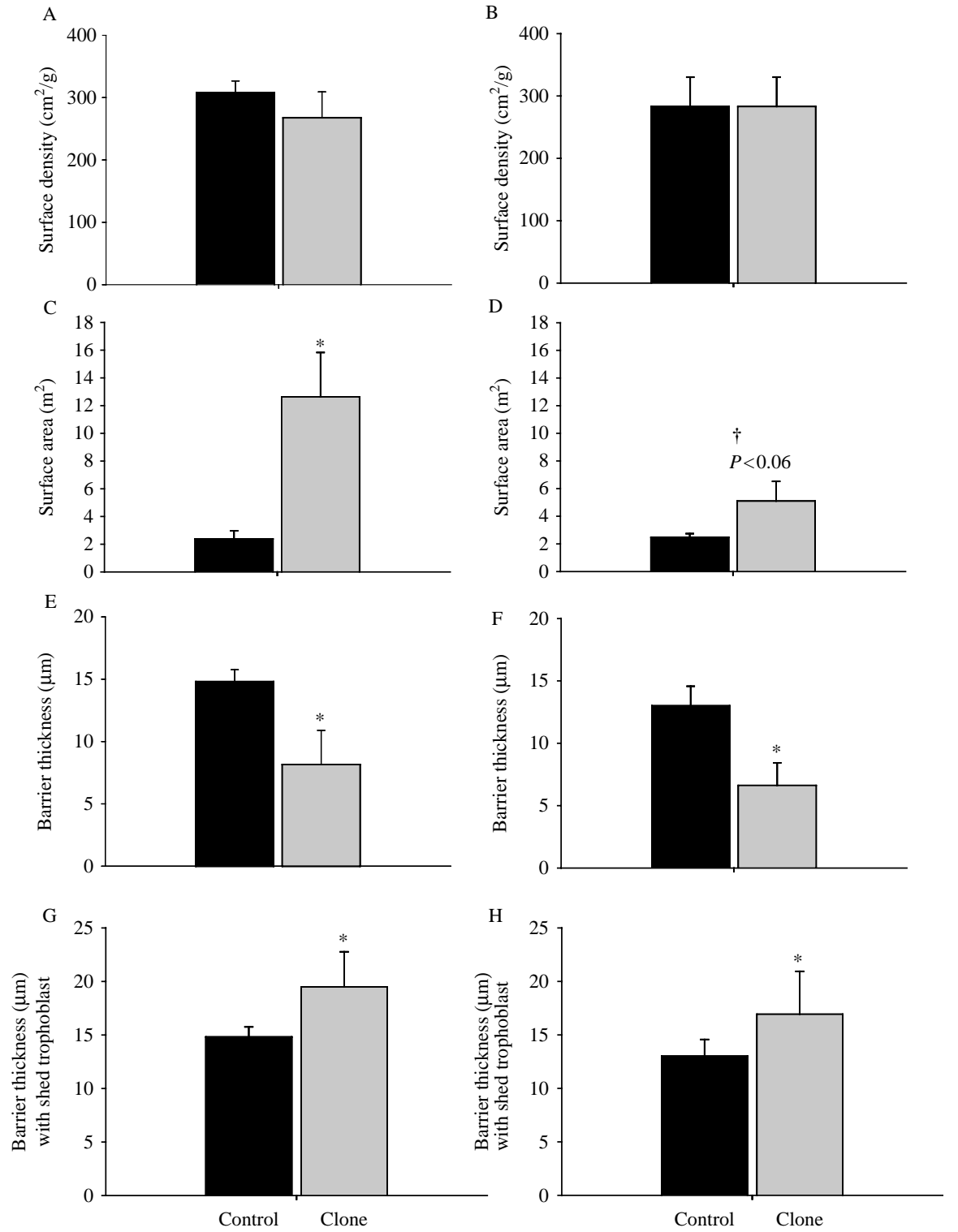
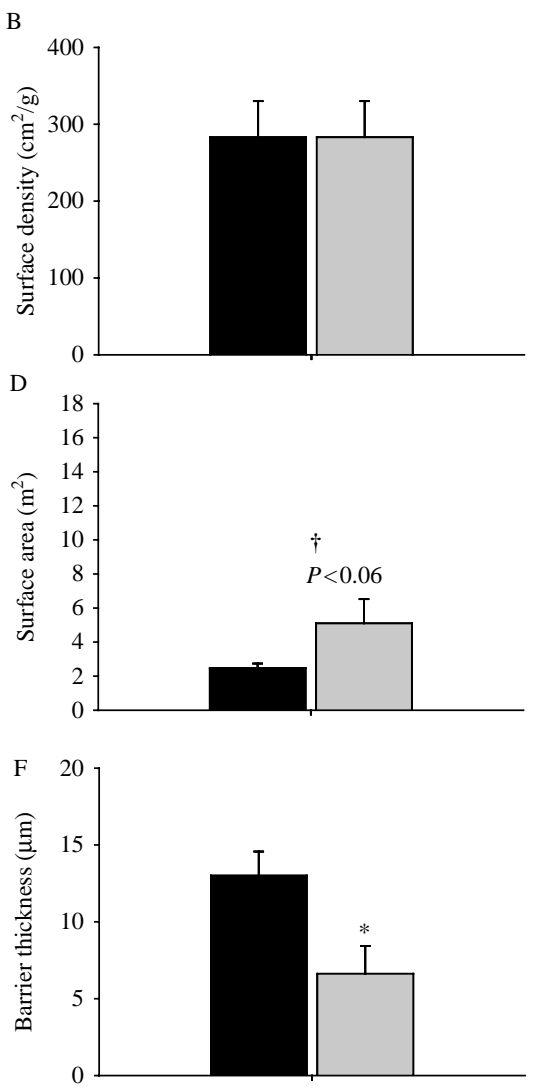

Figure 4 The effect of cloning on the surface density of trophoblast for exchange in the early age group

(A) and the later age group (B), surface area of trophoblast for exchange in the early age group $(\mathrm{C})$ and the later age group (D), barrier thickness of trophoblast for exchange for the early age group (E) and the later age group (F) and the barrier thickness of trophoblast adjusted for shed trophoblast in the early age group $(\mathrm{G})$ and the later age group $(\mathrm{H})$ in placentomes in the early age group. ${ }^{*}$ Denotes different from control $P \leq 0.05$.

${ }^{\dagger}$ Denotes difference between the early and the later age groups $P \leq 0.05$. GA, 105-134 days; control, $n=14$ and clone $n=5$; GA, 135-154 days; control, $n=6$ and clone $n=4$. $\left(32.11 \pm 9.95 \mathrm{~cm}^{3}\right)$ compared with alive fetuses $\left(121.54 \pm 12.18 \mathrm{~cm}^{3}\right)$ only in the early age group $(P<$ 0.02). This similar pattern was seen with regard to shed trophoblast. In other words, shed trophoblast was reduced in dead $\left(168.36 \pm 25.19 \mathrm{~cm}^{3}\right)$ compared with alive fetuses $\left(363.47 \pm 30.85 \mathrm{~cm}^{3}\right)$ only in the early age group $(P<0.02)$.

\section{Immunohistochemistry}

In order to determine whether aberrant placentome morphology was characteristic of clones or a consequence of fetal demise, sections from clone and control placentomes were subjected to immunohistochemistry for activated caspase-3, a caspase known to have a role in the cell apoptotic pathway. This analysis confirmed the presence of apoptotic, rather than necrotic cells in the clone placentomes, specifically in the shed trophoblast (Fig. 7A). In regions where no shed trophoblast was present, there was no activated caspase- 3 immunoreactivity (Fig. 7C).

\section{Plasma glucose concentrations}

There was no difference in maternal plasma glucose concentration between ewes carrying cloned and control fetuses immediately prior to post-mortem (Fig. 8A and B). Maternal plasma glucose concentrations were higher, however, later in pregnancy than before 135 days gestation $(P<0.0001)$. There was no difference 

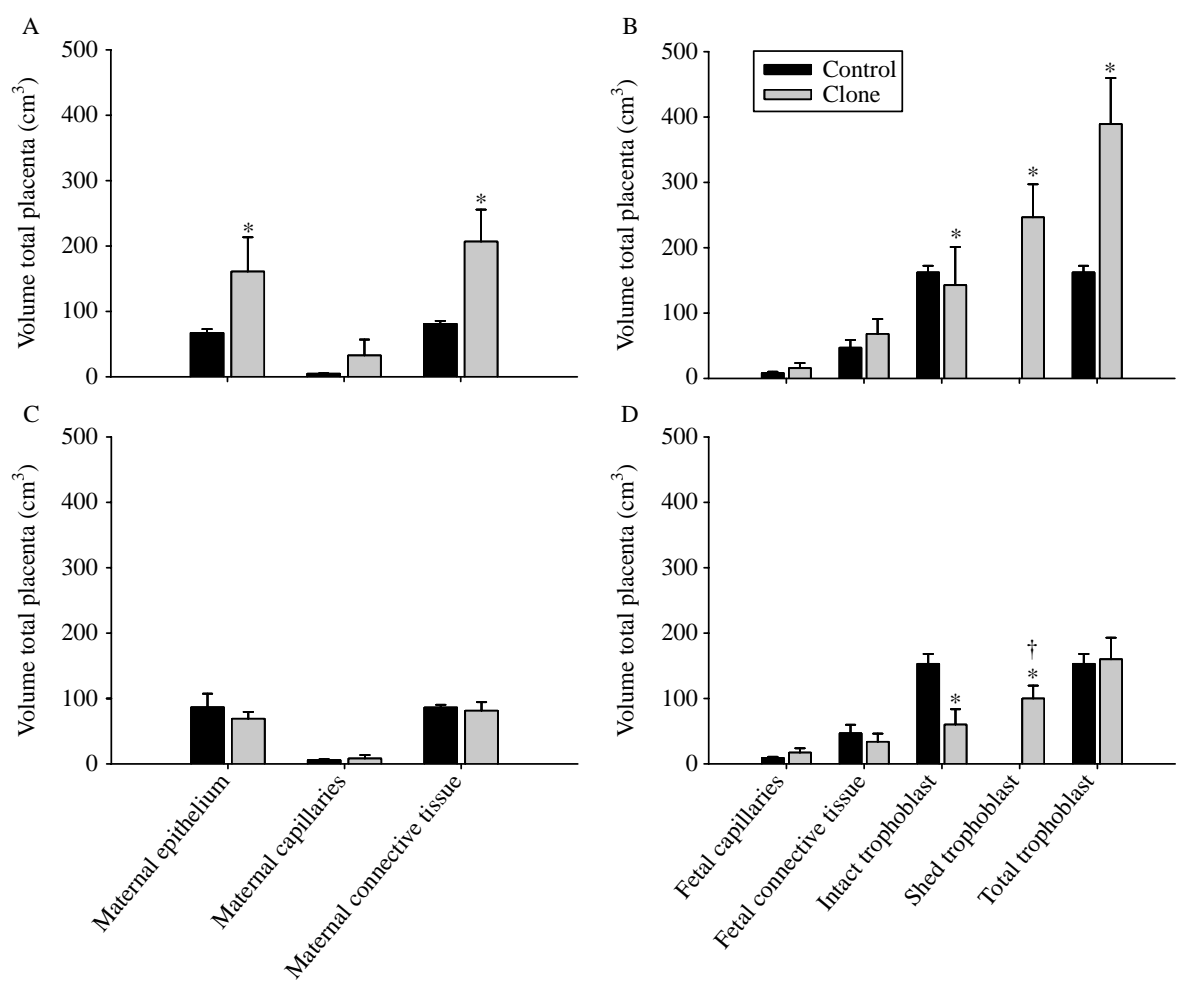

Figure 5 Effect of cloning on the calculated total volume of the placental components (mean \pm S.E.M.) for the early age group $(\mathrm{A}$ and $\mathrm{B})$ and the later age group $(\mathrm{C}$ and D). * Denotes different from control $P \leq 0.05$. ${ }^{\dagger}$ Denotes difference between the early and the later age groups $P<0.05$. GA, $105-134$ days; control, $n=14$; clone, $n=5$ and GA, 135-154 days; control, $n=6$ and clone, $n=4$.

in fetal plasma glucose concentration between clones and controls before 135 days gestation, but after 135 days, this was reduced in clones $(P<0.008$; Fig. 8B).

\section{Placental gene expression}

Similar concentrations $(\sim 2-8 \mu \mathrm{g} / \mu \mathrm{l})$ of total RNA were extracted from cloned and control placentomes. In all cases, $2 \mu \mathrm{g}$ of RNA was reverse transcribed with a final concentration of $\sim 75 \mathrm{ng}$ cDNA being added to each realtime PCR. Gene expression was quantified relative to cyclophilin. IGF-I and IGF1R mRNA expression relative to cyclophilin was similar in clones and controls (Fig. 9). IGF-II and IGF2R mRNA expression were decreased by over $50 \%$, while GLUT-1, 3, and 8 mRNA expressions were decreased by over $70 \%$ compared with controls (Fig. 9). However, reduced placental gene expression failed to reach statistical significance.

\section{Discussion}

This is the first study to have performed a histological examination of placentomes collected from cloned sheep pregnancies. We have found that there was a decrease in placentome number, an increase in placentome weight and an increase in the incidence of structural abnormalities within the placenta in cloned ovine pregnancies. At both before and after 135 days gestation, there was a decreased proportion of intact trophoblast in clone placentomes, which could be attributed to the presence of shed trophoblast that was
A

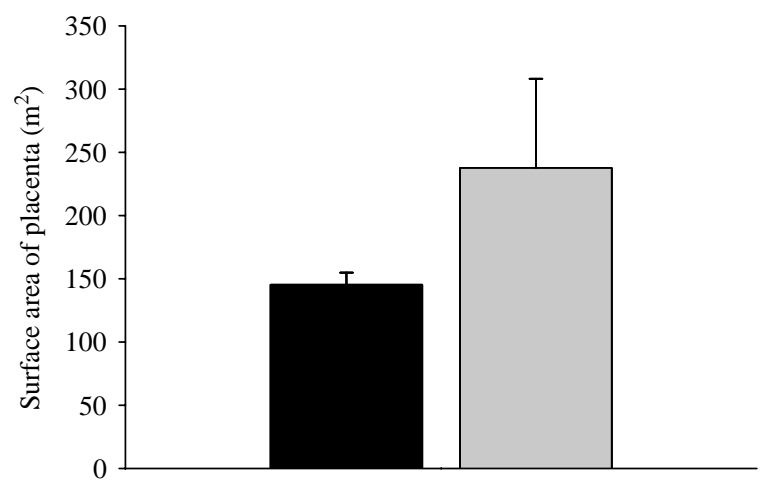

B

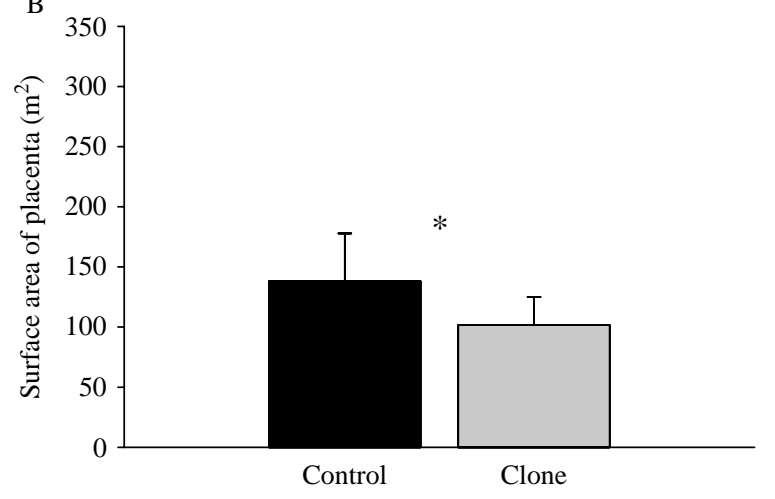

Figure 6 Effect of cloning on the surface area of trophoblast for exchange (mean \pm S.E.M.) calculated for the whole placenta for the early age group ( $A$ and $C$ ) and the later age group $(B$ and $D) .{ }^{*}$ Denotes difference between the early and the later age groups $P<0.05$. GA, 105-134 days; control, $n=14$; clone, $n=5$ and GA, 135-154 days; control, $n=6$ and clone, $n=4$. 

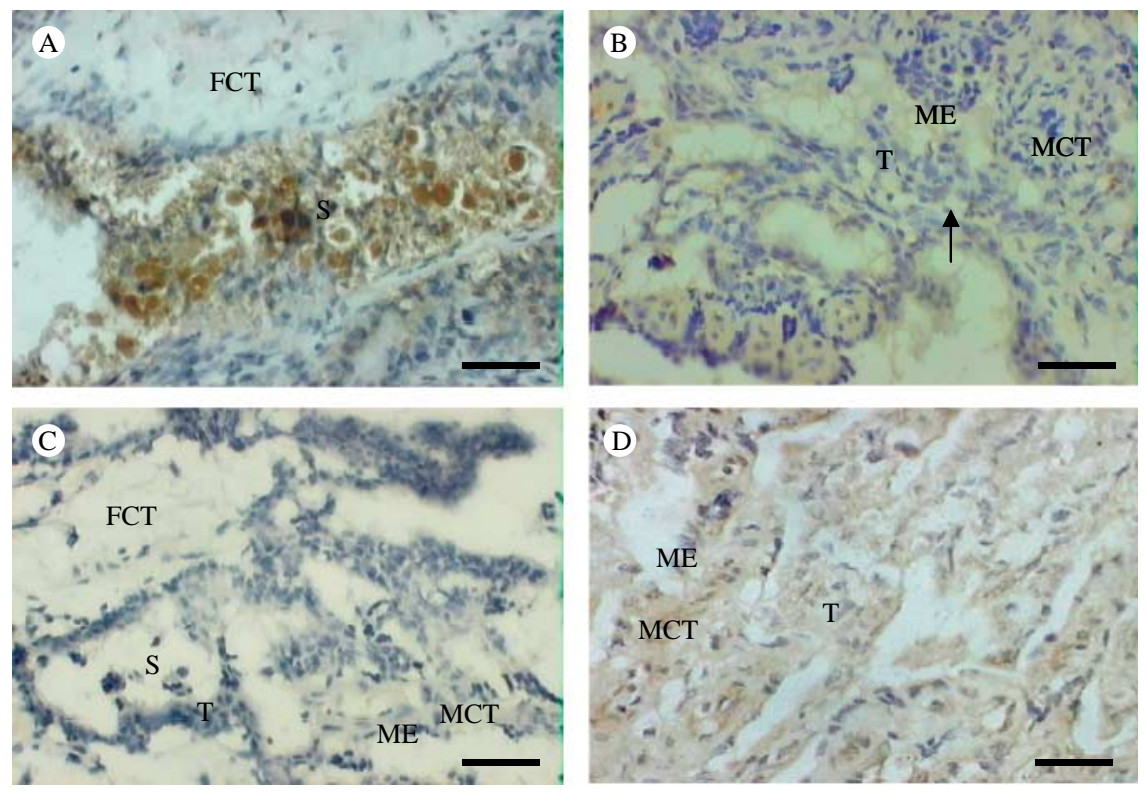

Figure 7 Activated caspase-3 staining in clone placentome sections showing shed trophoblast (A), intact feto-maternal interface (B) negative control (C). A control section with the addition of caspase-3 antibody is also shown (D). FCT, fetal connective tissue; ME, maternal epithelium; MCT, maternal connective tissue; T, trophoblast; S, fetal shed trophoblast. Solid arrow indicates fetal connective tissue. Scale bars $=200 \mu \mathrm{m}$. absent in control placentomes. This loss of trophoblast is unlikely to be due to post-mortem changes. Shed trophoblast was apoptotic in clones, irrespective of whether the tissue was collected immediately at postmortem or within hours after death. There was also more shed trophoblast present in the placentomes collected before 135 days gestation. In addition, there was no correlation between the volume density or volume of shed trophoblast with the timing of fetal demise or the state of the fetus at post-mortem. These suggest that trophoblast apoptosis and shedding and the associated villous hemorrhage occurs prior to, and may be causal in, fetal death.

In a recent publication examining the placental outcome of bovine clones, some differences to the present study were observed (Constant et al. 2006). Interestingly, in the cloned cow, placentome weight and number before and after 220 days gestation (term = 270 days) were different. We also found differences in cloned sheep placenta before and after 135 days gestation consistent with elevated fetal circulating cortisol concentrations following activation of the fetal HPA (Challis \& Brooks 1989). Cloning reduced placentome number and mean placentome weight in the cow before 220 days gestation, which is similar to the present observations in the younger age group in sheep clones. However, after 220 days gestation in the cow placentome number was not different, but mean placentome weight and total placental weight increased (Constant et al. 2006). We, on the other hand, observed reduced placentome numbers in clones after 135 days gestation but mean placentome weight and total placental weights were not different. Placental microstructure also differed in bovine clone placentomes. The volume density of fetal connective tissue was increased, while that of the maternal epithelium was decreased in
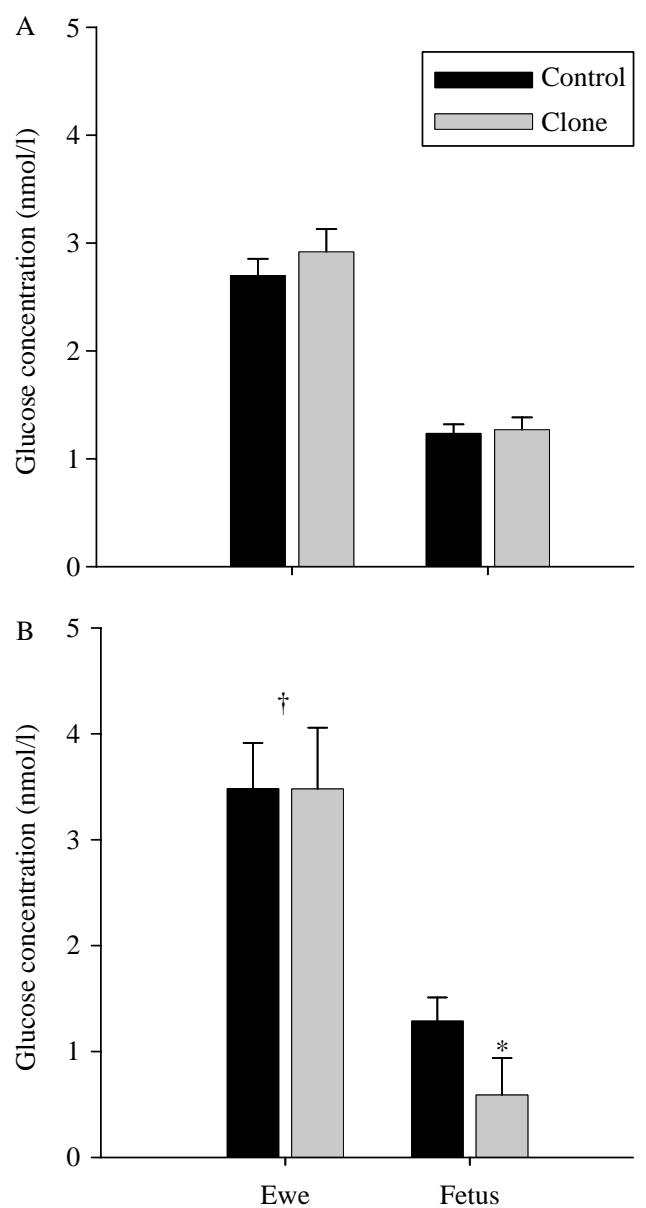

Figure 8 Effect of cloning on circulating glucose concentration $(\mathrm{nmol} / \mathrm{l})$ in the early age group immediately before post-mortem (A) and in the later age group immediately before post-mortem (B). *Denotes different from controls $P<0.05$. ${ }^{\dagger}$ Denotes difference between the early and the later age groups $P \leq 0.05$. GA, 105-134 days; control, $n=11$; clone, $n=6$ and GA, $135-154$ days; control, $n=9$ and clone, $n=5$. 


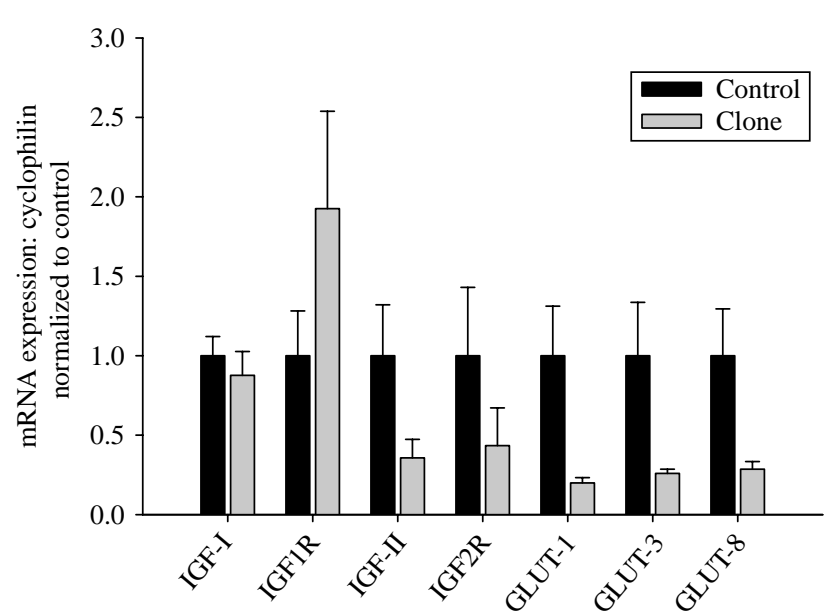

Figure 9 Effect of cloning irrespective of gestational age on mRNA expression of IGF-I (A), IGF1R (B), IGF-II (C), IGF2R (D), GLUT-1 (E), GLUT-3 (F), and GLUT-8 (G) relative to housekeeper cyclophilin and normalized to the control. Control, $n=12$ and clone, $n=4$.

bovine clones but not in the ovine clones in this study. Furthermore, there was no evidence of shed trophoblast in the clones compared with controls in the bovine placenta in contrast to the ovine placenta. The total placental surface area in bovine clones was not different before 220 days gestation, but was significantly higher in clones after 220 days gestation. The total placental surface area was not different between clones and controls in the present study, but after 135 days gestation the surface area was significantly reduced in comparison to before 135 days gestation. This suggests that the development of the placenta in bovine clones varies in some of the detail compared with ovine clones.

Hashizume et al. (2002) proposed that placental dysfunction in ruminant clones, specifically in early gestation, may be due to aberrant placental remodeling. Hashizume et al. (2002) found that there was high expression of factors which impair implantation and placentation at the feto-maternal interface (Wight et al. 1992, Cross et al. 1994, Clark et al. 1998), as well as reduced placentome numbers in early gestation (d60). They suggested that the increase in these factors resulted in compensatory hyperplasia of the maternal and fetal interplacentomal tissue (Hashizume et al. 2002). In the present study, the total volume of trophoblast (i.e. shed + intact trophoblast) was significantly greater in clones compared with controls at both gestational ages supporting the concept that there may be trophoblast hyperplasia in the clone placentomes. This is also consistent with the increased mean individual placentome weight albeit with reduced placentome numbers, observed in the present study.

Immunohistochemistry demonstrated that the shed trophoblast was immunoreactive for activated caspase3 , indicating that these trophoblast cells were apoptotic. In the normal ovine placenta, only small numbers of apoptotic cells are present and they occur in discrete clusters (Riley et al. 2000). This implies that apoptotic cells are usually removed from the placentoma, probably by phagocytosis (Riley et al. 2000). The extent of apoptosis of the trophoblasts is likely to have been too great to enable rapid removal of the shed cells by phagocytosis.

In a previous study in bovine cloned pregnancies, Lee et al. (2004) reported that $50 \%$ of the placentomes in early gestation were 'very red' possibly indicating good vascularization. We also observed macroscopically, that the placentomes from ovine cloned pregnancies were also very red, but histological analysis indicated that this was most likely due to fetal villous hemorrhage, possibly following trophoblast shedding, rather than enhanced vascularization. We have found that neither the volume density of the fetal nor that of the maternal, capillaries was altered by cloning throughout late gestation.

Defects in the clone placenta suggest that its function is likely to be impaired. This is consistent with the trend towards a reduction in the expression of key placental genes in clones compared with controls. In addition, fetal plasma glucose concentrations were reduced in clone pregnancies in late gestation suggesting decreased placental glucose transfer. Gene expression of the three key glucose transporter isoforms GLUT-1, GLUT-3, and GLUT-8, previously identified in ovine placental trophoblasts (Ehrhardt \& Bell 1997, Knipp et al. 1999, Das et al. 2000, Limesand et al. 2004) tended to be decreased in clone placenta. This may account for the reduced circulating glucose concentrations in the clones in late pregnancy.

IGF-II and IGF2R have key roles in placental development. IGF-II is a paternally expressed imprinted gene that promotes placental development, while IGF2R is a maternally expressed imprinted gene that inhibits placental growth (Reik et al. 2003). Deletion of IGF-II reduces both placental and fetal weights (DeChiara et al. 1990, Baker et al. 1993). When the placental specific IGF-II P0 promoter is ablated placental growth restriction occurs, followed by fetal growth restriction and there are also associated changes in the functional transfer capacity of the placenta (Constancia et al. 2002, 2005, Sibley et al. 2004). In contrast, IGF2R gene ablation increases circulating IGF-II and results in fetal and placental overgrowth (Wylie et al. 2003). This is likely to be a consequence of reduced clearance of IGF-II. There is also evidence suggesting the presence of a signal transduction cascade following IGF-II-IGF2R binding that increases placental trophoblast invasion in a human first trimester extravillous cytotrophoblast cell line (McKinnon et al. 2001). In sheep, both IGF-II and $I G F 2 R$ are parentally imprinted genes and they play similar roles in growth and development of the fetus and placenta (Hagemann et al. 1998, McLaren \& Montgomery 1999, Young et al. 2001). 
In the present study, there was a trend for reduced placental IGF-II and IGF2R mRNA expression in clones, while IGF-I and IGF1R mRNA expression was similar in control and clone placenta. Interestingly, it is well established that IGF-II has anti-apoptotic effects in a variety of cell lines (Christofori et al. 1994, Petrik et al. 1998, Leng et al. 2001) and the relative decrease in IGF-II mRNA expression in clones compared with controls may contribute to the apoptosis observed in the clone placenta.

Large offspring syndrome (LOS) has been reported in ruminants following cloning as well as in vitro culture (Willadsen et al. 1991, Wilson et al. 1995, Young et al. 1998). There were clones in our cohort that survived to term (not discussed in this paper) that had enlarged organs, specifically the liver, the heart, and the kidneys. Despite this, there was no increase in birth weight in the term clones compared with controls. This was also the case with fetal weight in the current cohort. A molecular mechanism for the occurrence of LOS has been proposed by Young et al. (2001) in which an epigenetic change in IGF2R leads to its reduced expression allowing IGF-II to promote fetal growth as it is not cleared from the circulation by IGF2R. In the present study, cloning tended to reduce both IGF-II and IGF2R expression in the placenta. Thus, it is likely that there was insufficient IGF-II to promote placental overgrowth. These effects may be tissue specific rather than global. The methylation status of IGF-II and IGF2R has been analyzed in clones previously (Young et al. 2003). IGF2R methylation in fetal tongue was reduced in clones compared with controls, but IGF-II methylation was unaffected by cloning. IGF-II mRNA expression was similar in clones compared with controls but IGF2R mRNA was not detected. The fetal weight of these clones was not reported and therefore changes in the gene expression cannot be correlated with fetal weight. In addition, no information on DNA methylation in placenta was reported.

In summary, we have demonstrated that there are structural and functional placental abnormalities present in failing clone pregnancies in the sheep. The presence of large volumes of apoptotic shed trophoblast and villous hemorrhage and a tendency for growth factor and glucose transporter gene expression to be reduced, may together contribute to the early demise of clones. The specific factors that induce widespread trophoblast apoptosis and other placental abnormalities in cloned pregnancies remain to be identified.

\section{Acknowledgements}

This work has been supported by the Australian Research Council and the National Health and Medical Research Council. The authors declare that there is no conflict of interest that would prejudice the impartiality of this scientific work.

\section{References}

Alexander G 1964a Studies on the placenta of the sheep (Ovis aries L.). Effect of surgical reduction in the number of caruncles. Journal of Reproduction and Fertility 30 307-322.

Alexander G 1964b Studies on the placenta of the sheep (Ovis aries L.). Placental size. Journal of Reproduction and Fertility 30 289-305.

Baker J, Liu JP, Robertson EJ \& Efstratiadis A 1993 Role of insulin-like growth factors in embryonic and postnatal growth. Cell 75 73-82.

Challis JR \& Brooks AN 1989 Maturation and activation of hypothalamic-pituitary-adrenal function in fetal sheep. Endocrine Reviews 10 182-204.

Chavatte-Palmer P, Heyman Y, Richard C, Monget P, LeBourhis D, Kann G, Chilliard Y, Vignon X \& Renard JP 2002 Clinical, hormonal, and hematologic characteristics of bovine calves derived from nuclei from somatic cells. Biology of Reproduction 66 1596-1603.

Chavatte-Palmer P, Remy D, Cordonnier N, Richard C, Issenman H, Laigre P, Heyman Y \& Mialot JP 2004 Health status of cloned cattle at different ages. Cloning and Stem Cells 6 94-100.

Christofori G, Naik P \& Hanahan D 1994 A second signal supplied by insulin-like growth factor II in oncogene-induced tumorigenesis. Nature 369 414-418.

Cibelli JB, Stice SL, Golueke PJ, Kane JJ, Jerry J, Blackwell C, Ponce de Leon FA \& Robl JM 1998 Cloned transgenic calves produced from nonquiescent fetal fibroblasts. Science 280 1256-1258.

Clark DE, Smith SK, Licence D, Evans AL \& Charnock-Jones DS 1998 Comparison of expression patterns for placenta growth factor, vascular endothelial growth factor (VEGF), VEGF-B and VEGF-C in the human placenta throughout gestation. Journal of Endocrinology 159 459-467.

Constancia M, Hemberger M, Hughes J, Dean W, Ferguson-Smith A, Fundele R, Stewart F, Kelsey G, Fowden A \& Sibley C 2002 Placental-specific IGF-II is a major modulator of placental and fetal growth. Nature 417 945-948.

Constancia M, Angiolini E, Sandovici I, Smith P, Smith R, Kelsey G, Dean W, Ferguson-Smith A, Sibley CP \& Reik W 2005 Adaptation of nutrient supply to fetal demand in the mouse involves interaction between the Igf2 gene and placental transporter systems. PNAS 102 19219-19224.

Constant F, Guillomot M, Heyman Y, Vignon X, Laigre P, Servely JL, Renard JP \& Chavatte-Palmer P 2006 Large offspring or large placenta syndrome? Morphometric analysis of late gestation bovine placentomes from somatic nuclear transfer pregnancies complicated by hydrallantois. Biology of Reproduction 75 122-130.

Cross JC, Werb Z \& Fisher SJ 1994 Implantation and the placenta: key pieces of the development puzzle. Science 266 1508-1518.

Das UG, He J, Ehrhardt RA, Hay WW Jr \& Devaskar SU 2000 Timedependent physiological regulation of ovine placental GLUT-3 glucose transporter protein. American Journal of Physiology. Regulatory, Integrative and Comparative Physiology 279 R2252-R2261.

DeChiara TM, Efstratiadis A \& Robertson EJ 1990 A growth-deficiency phenotype in heterozygous mice carrying an insulin-like growth factor II gene disrupted by targeting. Nature 345 78-80.

De Sousa PA, King T, Harkness L, Young LE, Walker SK \& Wilmut I 2001 Evaluation of gestational deficiencies in cloned sheep fetuses and placentae. Biology of Reproduction 65 23-30.

Drury RAB \& Wallington EA 1980 Carleton's Histological Technique, 5th edn. Oxford; New York: Oxford University Press.

Edwards LJ, Simonetta G, Owens JA, Robinson JS \& McMillen IC 1999 Restriction of placental and fetal growth in sheep alters fetal blood pressure responses to angiotensin II and captopril. Journal of Physiology 515 897-904.

Edwards L, Peura T, Hartwich K, Rudiger S, McMillen IC \& Walker S 2002 Postnatal growth and circulating ACTH and cortisol concentrations during the first month of life in cloned lambs. Endocrinology 143 3699-3702. 
Ehrhardt RA \& Bell AW 1997 Developmental increases in glucose transporter concentration in the sheep placenta. American Journal of Physiology 273 R1132-R1141.

Hagemann LJ, Peterson AJ, Weilert LL, Lee RS \& Tervit HR 1998 In vitro and early in vivo development of sheep gynogenones and putative androgenones. Molecular Reproduction and Development 50 154-162.

Hashizume K, Ishiwata H, Kizaki K, Yamada O, Takahashi T, Imai K, Patel OV, Akagi S, Shimizu M, Takahashi S et al. 2002 Implantation and placental development in somatic cell clone recipient cows. Cloning and Stem Cells 4 197-209.

Hill JR, Burghardt RC, Jones K, Long CR, Looney CR, Shin T, Spencer TE, Thompson JA, Winger QA \& Westhusin ME 2000 Evidence for placental abnormality as the major cause of mortality in first-trimester somatic cell cloned bovine fetuses. Biology of Reproduction 63 1787-1794.

Hill JR, Winger QA, Burghardt RC \& Westhusin ME 2001a Bovine nuclear transfer embryo development using cells derived from a cloned fetus. Animal Reproduction Science 67 17-26.

Hill JR, Edwards JF, Sawyer N, Blackwell C \& Cibelli JB 2001b Placental anomalies in a viable cloned calf. Cloning 3 83-88.

Hill JR, Schlafer DH, Fisher PJ \& Davies CJ 2002 Abnormal expression of trophoblast major histocompatibility complex class I antigens in cloned bovine pregnancies is associated with a pronounced endometrial lymphocytic response. Biology of Reproduction $\mathbf{6 7}$ 55-63.

Kato Y, Tani T, Sotomaru Y, Kurokawa K, Kato J, Doguchi H, Yasue H \& Tsunoda Y 1998 Eight calves cloned from somatic cells of a single adult. Science 282 2095-2098.

Knipp GT, Audus KL \& Soares MJ 1999 Nutrient transport across the placenta. Advanced Drug Delivery Reviews 38 41-58.

Lee RS, Peterson AJ, Donnison MJ, Ravelich S, Ledgard AM, Li N, Oliver JE, Miller AL, Tucker FC, Breier B et al. 2004 Cloned cattle fetuses with the same nuclear genetics are more variable than contemporary half-siblings resulting from artificial insemination and exhibit fetal and placental growth deregulation even in the first trimester. Biology of Reproduction 70 1-11.

Leng SL, Leeding KS, Gibson PR \& Bach LA 2001 Insulin-like growth factor-II renders LIM 2405 human colon cancer cells resistant to butyrate-induced apoptosis: a potential mechanism for colon cancer cell survival in vivo. Carcinogenesis 22 1625-1631.

Limesand SW, Regnault TR \& Hay WW Jr 2004 Characterization of glucose transporter 8 (GLUT8) in the ovine placenta of normal and growth restricted fetuses. Placenta 25 70-77.

McKinnon T, Chakraborty C, Gleeson LM, Chidiac P \& Lala PK 2001 Stimulation of human extravillous trophoblast migration by IGF-II is mediated by IGF type 2 receptor involving inhibitory G protein(s) and phosphorylation of MAPK. Journal of Clinical Endocrinology and Metabolism 86 3665-3674.

McLaren RJ \& Montgomery GW 1999 Genomic imprinting of the insulin-like growth factor 2 gene in sheep. Mammalian Genome 10 588-591.

Petrik J, Arany E, McDonald TJ \& Hill DJ 1998 Apoptosis in the pancreatic islet cells of the neonatal rat is associated with a reduced expression of insulin-like growth factor II that may act as a survival factor. Endocrinology 139 2994-3004.

Peura TT, Hartwich KM, Hamilton HM \& Walker SK 2003 No differences in sheep somatic cell nuclear transfer outcomes using serum-starved or actively growing donor granulosa cells. Reproduction, Fertility, and Development 15 157-165.

Reik W, Constancia M, Fowden A, Anderson N, Dean W, FergusonSmith A, Tycko B \& Sibley C 2003 Regulation of supply and demand for maternal nutrients in mammals by imprinted genes. Journal of Physiology 547 35-44.

Riley SC, Webb CJ, Leask R, McCaig FM \& Howe DC 2000 Involvement of matrix metalloproteinases 2 and 9, tissue inhibitor of metalloproteinases and apoptosis in tissue remodelling in the sheep placenta. Journal of Reproduction \& Fertility 118 19-27.
Roberts CT, Sohlstrom A, Kind KL, Earl RA, Khong TY, Robinson JS, Owens PC \& Owens JA 2001 Maternal food restriction reduces the exchange surface area and increases the barrier thickness of the placenta in the guinea-pig. Placenta 22 177-185.

Sibley CP, Coan PM, Ferguson-Smith AC, Dean W, Hughes J, Smith P, Reik W, Burton GJ, Fowden AL \& Constancia M 2004 Placentalspecific insulin-like growth factor 2 (Igf2) regulates the diffusional exchange characteristics of the mouse placenta. PNAS 101 8204-8208.

Simon P 2003 Q-gene: processing quantitative real-time RT-PCR data. Bioinformatics 19 1439-1440.

Tanaka S, Oda M, Toyoshima Y, Wakayama T, Tanaka M, Yoshida N, Hattori N, Ohgane J, Yanagimachi R \& Shiota K 2001 Placentomegaly in cloned mouse concepti caused by expansion of the spongiotrophoblast layer. Biology of Reproduction 65 1813-1821.

Vatnick I, Ignotz G, McBride BW \& Bell AW 1991 Effect of heat stress on ovine placental growth in early pregnancy. Journal of Developmental Physiology 16 163-166.

Wakayama T, Perry AC, Zuccotti M, Johnson KR \& Yanagimachi $R$ 1998 Full-term development of mice from enucleated oocytes injected with cumulus cell nuclei. Nature 394 369-374.

Weibel ER 1979 Stereological Methods. London: Academic Press.

Wells DN, Misica PM, Day TA \& Tervit HR 1997 Production of cloned lambs from an established embryonic cell line: a comparison between in vivo- and in vitro-matured cytoplasts. Biology of Reproduction 57 385-393.

Wells DN, Misica PM \& Tervit HR 1999 Production of cloned calves following nuclear transfer with cultured adult mural granulosa cells. Biology of Reproduction 60 996-1005.

Wight TN, Kinsella MG \& Qwarnstrom EE 1992 The role of proteoglycans in cell adhesion, migration and proliferation. Current Opinion in Cell Biology 4 793-801.

Willadsen SM, Janzen RE, McAlister RJ, Shea BF, Hamilton G \& McDermand D 1991 The viability of late morulae and blastocysts produced by nuclear transplantation in cattle. Theriogenology 35 161-170.

Wilmut I, Schnieke AE, McWhir J, Kind AJ \& Campbell KH 1997 Viable offspring derived from fetal and adult mammalian cells. Nature $\mathbf{3 8 5}$ 810-813.

Wilson JM, Williams JD, Bondioli KR, Looney CR, Westhusin ME \& McCalla DF 1995 Comparison of birth weight and growth characteristics of bovine calves produced by nuclear transfer (cloning), embryo transfer and natural mating. Animal Reproduction Science 38 73-83.

Wylie AA, Pulford DJ, McVie-Wylie AJ, Waterland RA, Evans HK, Chen YT, Nolan CM, Orton TC \& Jirtle RL 2003 Tissue-specific inactivation of murine M6P/IGF2R. American Journal of Pathology $162321-328$.

Young LE, Sinclair KD \& Wilmut I 1998 Large offspring syndrome in cattle and sheep. Reviews of Reproduction 3 155-163.

Young LE, Fernandes K, McEvoy TG, Butterwith SC, Gutierrez CG, Carolan C, Broadbent PJ, Robinson JJ, Wilmut I \& Sinclair KD 2001 Epigenetic change in IGF2R is associated with fetal overgrowth after sheep embryo culture. Nature Genetics 27 153-154.

Young LE, Schnieke AE, McCreath KJ, Wieckowski S, Konfortova G, Fernandes K, Ptak G, Kind AJ, Wilmut I, Loi P et al. 2003 Conservation of IGF2-H19 and IGF2R imprinting in sheep: effects of somatic cell nuclear transfer. Mechanisms of Development $\mathbf{1 2 0}$ $1433-1442$.

Received 4 April 2006

First decision 24 April 2006

Revised manuscript received 1 September 2006

Accepted 6 November 2006 